\title{
sciendo
}

\section{The International Conference on Development and Applications of Nuclear Technologies, NUTECH-2020, Warsaw, Poland, 4-7 October 2020}

On 4-7 October 2020, the Institute of Nuclear Chemistry and Technology (INCT) in Warsaw was honoured to host the International Conference on Development and Applications of Nuclear Technologies NUTECH-2020, organized in cooperation with the University of Science and Technology in Kraków (AGH) and the Polish Nuclear Society (PTN).

The conference has a long tradition in Poland. It has been organized periodically as National Symposia on Applications of Nuclear Techniques in Industry, Agriculture, Medicine and Environment Protection, since 1960, almost every three years; and in 2008 it attained international status, which it maintains up to the present day.

Due to the coronavirus disease (COVID-19) pandemic, for the first time, the NUTECH conference was organized in a hybrid form. Participants could take part in the conference in person or online. All lectures were broadcast via a dedicated conference platform. The main aim of the NUTECH-2020 conference was to bring together scientists working in the field of nuclear and radiation technologies to facilitate scientific contacts and collaboration among the scientific community. The conference witnessed the participation of a houndred scientists from all over the world, including 38 from abroad. Half of the registered participants took part in the conference in person and half online. A total of 92 abstracts were submitted to the conference, comprising 45 oral presentations, and 47 poster presentations, which were in the form of short presentations.

We were pleased to host representatives of Polish authorities: the National Atomic Energy Agency (PAA) President, Dr Łukasz Młynarkiewicz, who welcomed the conference participants, Andrzej Głowacki, Vice-President of PAA participated in the opening of the NUTECH-2020 conference personally and Director of the Department of Nuclear Energy, Dr Tomasz Nowacki who gave the welcome speech to conference participants online.

We were also honoured to host Prof. Piotr Ulański, Dr Jerzy Majcher, Prof. Suresh Pillai, Prof. Mohamad AL-Sheikhly, representatives of the International Atomic Energy Agency (IAEA), namely Dr Bumsoo Han, and Dr Patrick Brisset, who delivered lectures in the plenary session on the conference opening day, as well as invited speakers: Dr Ziemowit Iwański, Prof. Wacław Gudowski,

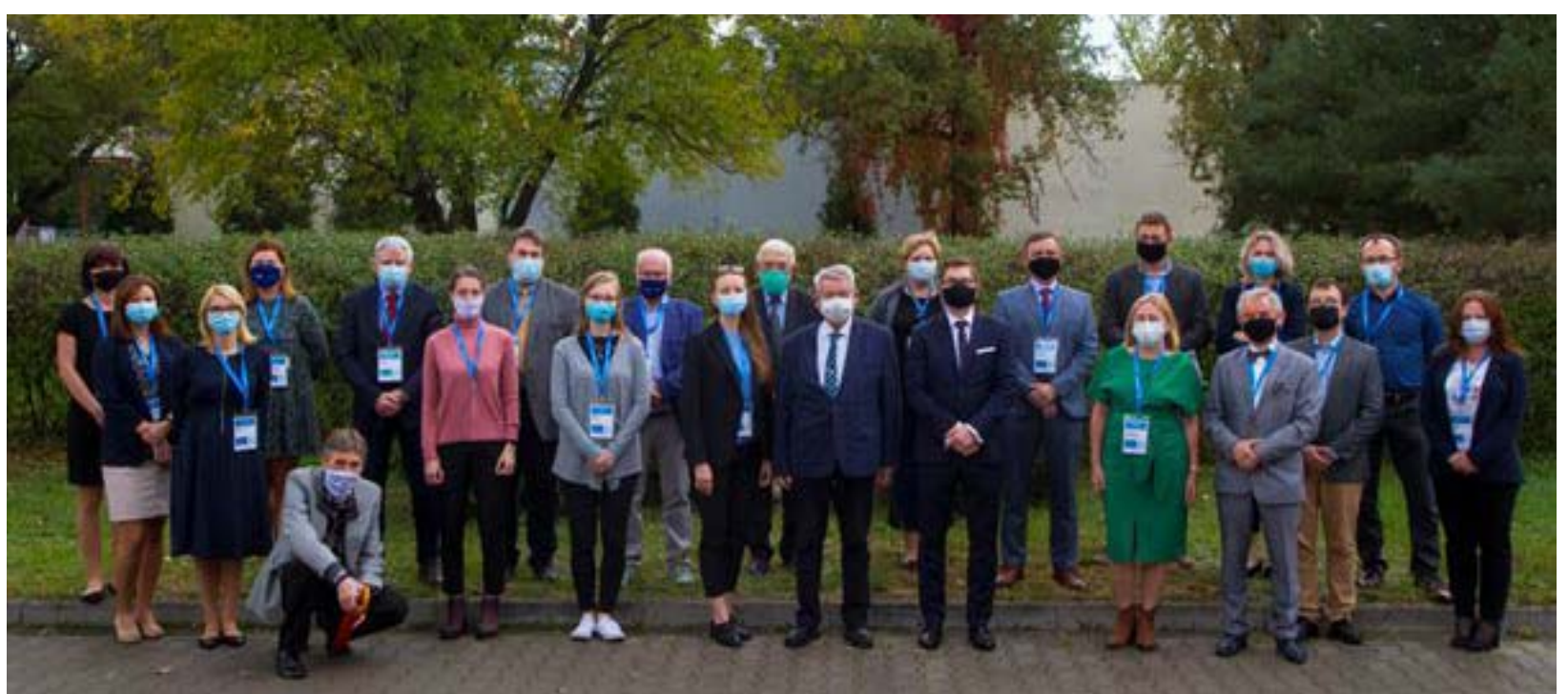

0029-5922 (c) 2021 The Author(s). Published by the Institute of Nuclear Chemistry and Technology.

This is an open access article under the CC BY-NC-ND 4.0 licence (http://creativecommons.org/licences/by-nc-nd/4.0/). 
Prof. Mariusz Dąbrowski, Dr Mirco Grosse, Dr Heinz Nabielek and Prof. Nikolay Kuksanov.

The sessions were dedicated to the achievements realized thus far in the field of nuclear physics and the future of nuclear energy, radioisotopes and medical application of ionizing radiation, radiation technologies and applications. Two special sessions were also organized, and these were dedicated to the application of electron beam accelerators (ARIES H2020 project) and tracers and radiotracers applications (ISTRA).

We would like to thank the conference co-chairmen Prof. Andrzej G. Chmielewski and Prof. Marek Lankosz, the scientific committee chaired by Prof. Grażyna Zakrzewska-Kołtuniewicz, organizing committees chaired by Prof. Wojciech Migdał and Mazurkas Congress Management for their valuable help and involvement, which have made NUTECH-2020 a great success.

We would like to thank all participants who, by their participation, contributed to the benchmark of high scientific temper that was maintained in the conference.

This Special Issue of "Nukleonika" contains a selection of the papers presented at the
NUTECH-2020 Conference. It may serve as an overview of international activities and contributions to research on nuclear and radiation technologies. Our sincere thanks go to all members of the Scientific Committee of the NUTECH-2020 for support in nominating the invited speakers and maintaining the high standard of this conference. Due to the efforts of the authors as well as the dedication of the reviewers, this Special Issue satisfies the scientific and publishing standards.

We would like to also acknowledge the institutions that supported the NUTECH-2020: Ministry of Science and Higher Education, Ministry of Climate, National Atomic Energy Agency and Office of Technical Inspection for their honorary patronage of the conference. We express our gratitude to the Ministry of Science and Higher Education for the financial support of the NUTECH-2020 Conference in the frame of the programme "Doskonała Nauka". This financial contribution made it possible to publish this Special Issue of "Nukleonika".

Dagmara Chmielewska-Śmietanko, Urszula Gryczka Guest Editors 